\title{
動機と行動の関連性についての素朴理論'
}

\author{
伊藤公一郎 ${ }^{2}$ 名古屋大学 $^{3}$ 池上知子 大阪市立大学 ${ }^{4}$
}

\section{Naive theories about the relationship between motives and behaviors}

Koichiro Ito (Nagoya University) and Tomoko Ikegami (Osaka City University)

\begin{abstract}
People have naive theories about the relationship between motives and behaviors. Based on recent developments in attribution theories and negativity bias in social perception, we hypothesized that people would associate negative behaviors only with negative motives, while they would associate positive behaviors with not just positive, but also negative motives. These hypotheses were tested in three studies. In Studies 1 and 2, we found that behavioral information inconsistent with naive theories was best recalled under conditions with no cognitive load. However, this recall advantage dissipated when participants were under time pressure during the encoding of the behavioral information. In Study 3, participants were presented with positive and negative behaviors, and were asked to infer the actors' motives from these behaviors. The results showed that naive theories guided their inferences: negative motives were likely to be inferred from negative behaviors, whereas both negative and positive motives were inferred from positive behaviors. Implications for attribution theories and negativity bias in social perception are discussed.
\end{abstract}

Key words: motive attributions, attribution theories, reason explanations, negativity bias.

The Japanese Journal of Psychology

2006, Vol. 77, No. 5, pp. 415-423

他者の行動の背後にある動機を推論することは, 行 為者についての評価を下したり，その行動によっても たらされる結果を予測したりするのに必要不可欠であ る。しかしながら，動機は目に見えない構成概念であ り，直接それを知ることが不可能である以上，いかな る動機を推論するかは知覚者の主観に委ねられている といえる。そのため, 人々が主観的に行う動機の推論 にどのような傾向がみられるかを明らかにすることは 重要であるといえるだろう。本研究では, 様々な行動 とその背後にある動機との関連性について, 人々が暗 黙の信念を持っており, その信念に基づいて動機を推

Correspondence concerning this article should be sent to: Tomoko Ikegami, Department of Psychology, Graduate School of Literature and Human Sciences, Osaka City University, Sumiyoshi-ku, Osaka 558-8585, Japan (e-mail: ikegami@lit. osaka-cu.ac.jp)

1 本研究は, 第 2 著者の指導のもとに第 1 著者が愛知教育大 学大学院教育学研究科に提出した修士論文をまとめ直したもの である。

2 伊藤公一郎氏は2006 年 10 月に交通事故に遭い亡くなられ ました。謹んで哀悼の意を表します。

3 本研究を実施した時点での所属は愛知教育大学大学院教育 学研究科であった。

4 本研究を実施した時点での所属は愛知教育大学教育学部で あった。
論し行動を理解するということを提案し，それを三つ の研究によって検証する。最初に, Ybarra (2002) が提唱した行動の素朴な因果理解に関する理論化と近 年の帰属理論の研究動向を参考にしながら, その信念 の性質を論じる。

Ybarra（2002）は，人は様々な規範を有する社会 の中に生きており，また，そういった社会に適合しょ うとする欲求を持っているために，社会的に好ましい （ポジティブな）行動は促進され，社会的に好ましく ない（ネガティブな）行動は抑制されると論じてい る。このような社会の中で他者の行動を観察し学習す ると, 人が行うポジティブな行動は規範的圧力（外的 要因）に従ったものであるとみなす傾向が高まる。他 方, ネガティブな行動は, 規範的圧力に反する行動で あると解釈され, それは行為者の性格特性（内的要 因）が原因となって生じたものであるとみなすように なる。すなわち, 人はポジティブな行動と外的要因 を，そして，ネガティブ行動と内的要因を関連づける 素朴な因果理解を形成するようになるという。

人々がこのような因果理解を形成している可能性を 示唆する研究はいくつか存在する。例えば, Miller （1984）は，身近な人物の行った行動の理由を説明さ せると, 人はポジティブな行動については外的要因 
を, ネガティブな行動については内的要因を挙げる傾 向にあることを見出している。また，Ybarra \& Stephan（1996）は，ポジティブな行動は外的要因, ネガティブな行動は内的要因によって生起するという 素朴な因果理解に一致する行動情報は, 一致しない行 動情報よりも再生されやすいこと，その傾向は認知的 な負荷をかけた場合であっても変わらないことを示し た。以上の知見は，人はポジティブな行動と外的要因 を，ネガティブな行動と内的要因を関連づけて理解す るという Ybarra（2002）の主張と整合しているとい えよう。

ところで, 近年の㷌属理論研究者 (Kammrath, Mendoza-Denton, \& Mischel, 2005; Malle, 2004; McClure, 2002; Reeder, Vonk, Ronk, Ham, \& Lawrence, 2004）は，人が他者の行動を理解するため には，その人物の心的状態（e.g., 動機，意図）を推論 することが重要であると主張している。例えば，上位 者に取り入ろうとして援助行動をする場合と，特別な 利害関係のない他者に自ら進んで援助行動をする場合 とでは，同じ援助行動であってもその意味は異なり， 利己的な動機が推論される前者の行動はより低く評価 される（Reeder et al., 2004）。Malle（1999）は，意図 性の異なる様々な行動を調查協力者に提示し, 行為者 が “なぜその行動を行ったか”を推測して自由に記述 するよう求めたところ，意図性の高い行動を説明する 際には行為者の欲求や信念といった心的状態に言及し やすいことを明らかにしている。

そこで, 本研究では, 心的状態の役割を重視する近 年の帰属理論の研究動向を踏まえ，かつYbarra （2002）の見解を参考にしながら，動機の推論の性質 について検討することにした。Ybarra（2002）が論 じたように，我々がポジティブな行動をするよう促さ れる規範的圧力の中に生きているのであれば，ポジテ イブな動機を持っていたとしても，また，ネガティブ な動機を持っていたとしても，人は可能な限りポジテ イブな行動をするはずである。そのような社会で他者 の行動を観察し学習すれば, 人はポジティブな行動の 背後にポジティブな動機を推論するだけでなく，ネガ ティブな動機をも推論する傾性も持つようになると考 えられる。一方，ネガティブな行動は社会的規範をあ えて破る行動であり，人々はその行動の背後にはネガ ティブな動機があると当然のように考えるであろう。 すなわち，人は，ネガティブな行動からネガティブな 動機は推論するが，ポジティブな動機を推論すること は稀であると考えられる。

以上の考察を踏まえて，本研究では，ポジティブな 行動はポジティブな動機とネガティブな動機の両者に 関連づけ，そして，ネガティブな行動はネガティブな 動機にもっぱら関連づけるという動機と行動の関連性 についての素朴理論を人々が持っていると提案し, 三
つの実証的研究を行い検証する。先述のように， Ybarra \& Stephan（1996）は，原因に関する情報が付 加された様久な行動についての再生記憶が内的要因一 外的要因と行動の関連についての素朴理論の影響を受 けることを示し, その存在を主張した。研究 1 と研究 2 では，Ybarra \& Stephan（1996）に倣い，行動情報 の再生記憶を指標として，人が動機と行動の関連性に ついての素朴理論を持っているかどうかを検証する。 研究 3 では, ポジティブな行動とネガティブな行動を 調查協力者に提示し，その行動の背後にある動機を自 由に記述させることにより，素朴理論に沿った動機の 推論を行うかどうかを検証する。

\section{研 究 1}

Ybarra \& Stephan (1996, Experiment 2) は, 行動 とその要因との関連性についての素朴理論を人々が持 っていることの根拠として, 素朴理論に一致する内容 の行動情報（i.e., 外的要因に帰属されたポジティブな 行動，内的要因に帰属されたネガティブな行動）がそ うでない行動情報に比べて再生されやすいという実験 結果を報告した。研究1では, Ybarra \& Stephan （1996）に準ずる実験手続きを用いる。もし人が先述 のような動機と行動の関連性についての素朴理論を持 つているのであれば, Ybarra \& Stephan（1996）の知 見と同様に，素朴理論に一致する内容の行動情報の再 生がその他の行動情報の再生に比べて多くなるはずて ある。すなわち，ポジティブな動機に基づくポジティ ブな行動とネガティブな動機に基づくポジティブな行 動，そしてネガティブな動機に基づくネガティブな行 動は，ポジティブな動機に基づくネガティブな行動よ りも再生されやすいと予測される。

\section{方 法}

実験参加者 25 名の大学生（すべて女性）であっ $た^{5}$ 。

行動記述文 研究 1 で使用する行動記述文は予備調 查 $(N=43)$ によって選定された。予備調査では, ま ず，行動記述文（e.g., 子どもを怒鳴りつけた）を 50 文提示して，各 “行動自体” の好ましさを評価させ， その後, それらの行動に動機の推論を可能にする文脈 情報を付加した 100 個の行動記述文 (e.g., 近所で火遊 びをしていた子ぞもを怒鳴りつけた）を提示し，その 行為の背後にあると考えられる “動機の”好ましさを 評定させている。それぞれの評定は 7 件法（1：非常 に好ましくないー7：非常に好ましい）で行われた。 この予備調査の結果から, 行動および動機の評定平均 值が中点（4 点）よりも大きいか小さいかを基準にし

5 通常, 行動の記憶に関する研究で性差はみられないが, 男 性を実験参加者として結果が再現できるかどうかは今後の課題 である。 
て，ポジティブな動機に基づくポジティブな行動を表 した行動記述文を 5 文（e.g., 被災地で人が困っている と聞いたので，ボランティア活動に参加した：行動の 評定は $M=4.91-5.88, S D=0.83-1.13$, 動機の評定 は $M=5.09-6.26, S D=0.79-1.23)$ ，ネガティブな 動機に基づくポジティブな行動を表した行動記述文を 5 文（e.g., お詫びのしるしにお金をもらったので，友 人の過ちを許した：行動の評定は $M=4.58-6.02$, $S D=0.80-1.04$, 動機の評定は $M=2.79-3.84$, $S D=0.94-1.46)$ ，ポジティブな動機に基づくネガテ イブな行動を表した行動記述文を 5 文（e.g., 本人の成 長につながるので，新入社員にわざと仕事を押しつけ た：行動の評定は $M=1.81-3.07, S D=0.84-1.27$, 動機の評定は $M=4.33-5.52, S D=0.92-1.27)$ ， ネ ガティブな動機に基づくネガティブな行動を表した行 動記述文を 5 文 (e.g., その高名な医者は金持ちだった ので,こびを売った：行動の評定は $M=2.21-3.12$, $S D=0.89-1.16$, 動機の評定は $M=1.91-2.67$, $S D=0.81-1.21 ）$ の計 20 文を選定した 6 。

実験装置 実験の制御はパーソナル・コンピュータ (SHARP, FJ520R) で行った。行動記述文の提示には Microsoft Office PowerPoint 2003 を使用し，プロジェ クタを介して立て掛け型の大型スクリーン上に提示し た。

手続き 実験は 1-3 名で行われた 7 。実験の協力に 関する同意書の内容を確認，署名してもらった後に， 実験の目的について, “他者の行動を評価する傾向と 数学的な処理能力との関連を調べる研究である”と偽 つて説明した。最初に練習試行として, 注視点 $(++++)$ を 5 秒間提示した後に評価的にニュート ラルな行動記述文をスクリーンに 20 秒間提示し，そ の間に行動の好ましさを 7 件法（1：非常に好ましく ないー7：非常に好ましい）で評定し配布した評定用 紙に回答してもらった。

次に本試行が行われた。本試行では, 予備調査で選 ばれた 20 の行動記述文をランダムな順番で 1 文ずつ 各文 20 秒間提示した。その 20 文に加えて, 最初の 1 文と最後の 2 文には記憶における初頭効果と新近効果 を消去するためにニュートラルな行動記述文を提示し た。各行動記述文が提示される直前には注視点が 5 秒 間提示された。行動記述文が提示されている 20 秒の 間に, 練習試行と同様に 7 件法の尺度で各行動の好ま しさを評定してもらった。本試行終了後, 短期記憶に

6 予備調査と使用した行動記述文の詳細については第 2 著者 に問い合わせされたい。

実験は小さな実験室で行われたため, 3 名が同時に実験に参 加する場合には， 1 人が 2 人の前の席に座ることになったが，提 示される行動記述文が見えにくくないよう座席を配列した（ス クリーンから座席の前列までの距離は約 $2 \mathrm{~m}$, 後列までの距離 は約 $3 \mathrm{~m}$ )。また, 提示された行動記述文の文字の大きさについ ても，見えにくくないよう配慮した。
残っている行動情報を消去するための挿入課題とし て, 簡単な計算課題に 3 分間取り組んでもらった。

計算課題終了後, 提示した行動文の自由再生を求め た。できるだけ多く，できるだけ正確に，思い出した ものから順番に配布した回答用紙に記述してもらつ た。また，文言が正確に思い出せない場合には，覚え ているおよその意味内容を記述するよう教示した。再 生課題の制限時間は 8 分間であった。再生課題終了 後, デブリーフィングを行った。再生課題を予期して いた参加者や仮説に気づいていた参加者はいなかっ た。

\section{結果と考察}

行動の評価 行動の種類ごとに評定値の平均を算出 し， 1 要因の分散分析（ANOVA）を行ったところ有 意であったため $(F(3,72)=185.32, p<.01)$, Ryan 法による多重比較を行った。その結果, すべての水準 間で有意差がみられた $(p s<.01)$ 。すなわち，ポジテ イブな動機に基づくポジティブな行動 $(M=5.98$, $S D=0.51)$ ，ポジティブな動機に基づくネガティブな 行動 $(M=4.35, S D=0.58)$ ，ネガティブな動機に基 ブくポジティブな行動 $(M=3.54, S D=0.61)$, ネガ ティブな動機に基づくネガティブな行動 $(M=2.13$, $S D=0.65)$ という順で好ましく評価されていた。こ れは, 単に行動の好ましさだけでなく, 動機の好まし さも考慮して評価された結果であるといえ，ここで使 用した行動記述文が妥当であったということを示唆し ている。

行動の記憶 回答はおおむね正しく再生できている ものを正再生とみなした。実験参加者が再生したすべ ての行動記述文について，正再生とみなせるかどうか を 2 人のコーダーが判断した結果，その一致率は 97.9 \%であった。コーダー間で一致しなかった回答は話し 合いによって正再生とみなすかどうかが判断された。 行動の種類ごとに平均正再生数を算出した。Figure 1

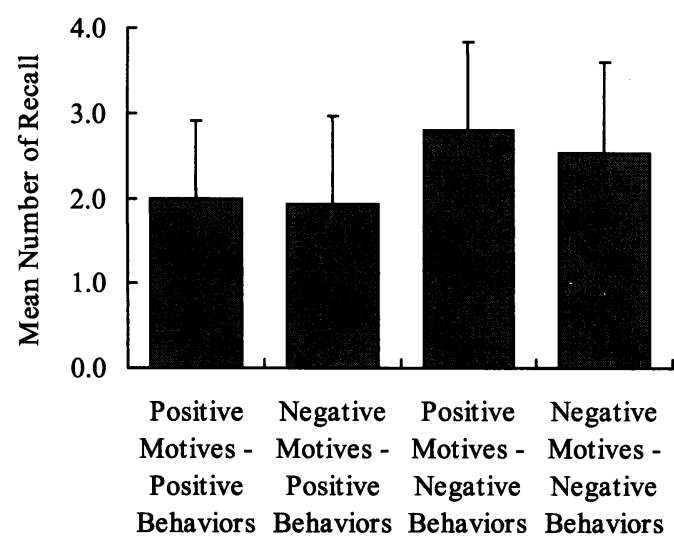

Figure 1. Mean free recall by behavior type. 
に示されているとおり，再生パターンは当初の予測と は異なっていた。そのため, 探索的な分析として 1 要 因の ANOVA を行ったところ主効果が有意であった $(F(3,72)=4.50, p<.01)$ 。Ryan 法による多重比較の 結果，ポジティブな動機に基づくネガティブな行動 は，ポジティブな動機に基づくポジティブな行動より も再生数が多く $(t(72)=2.85, p<.03)$, さらに, ネ ガティブな動機に基づくポジティブな行動よりも有意 に再生数が多かった $(t(72)=3.13, p<.03)$ 。ポジテ イブな動機に基づくポジティブな行動とネガティブな 動機に基づくポジティブな行動の再生数の間に有意な 差はみられなかった $(t<1)$ 。また，ネガティブな動 機に基づくネガティブな行動は，ポジティブな動機に 基づくポジティブな行動やネガティブな動機に基づく ポジティブな行動よりもやや再生数が多かったが，そ の差は統計的に有意ではなく, どの行動情報と比較し ても有意な差はみられなかった（ $t s<2.14 ） 。$

以上の結果は, Ybarra \& Stephan(1996)の論理に従 って最初に予測していた再生パターンとは異なってい た。すなわち，他の種類の行動に比べて再生されにく いと予測していたポジティブな動機に基づくネガティ ブな行動が反対に最もよく再生されていた。しかしな がら，この結果は異なる視点から解釈することができ る。なぜなら, 人には暗然の信念や期待に反する予想外 の社会的事象に対してょり多くの注意を向け，作業記 憶において精緻な処理を行う傾向があり，その結果と してそれらの事象の記憶に優れるという知見が存在す るからである (Macrae, Bodenhausen, Schloerscheidt, \& Milne, 1999)。これらの知見を考慮すれば，人は先 述のような動機と行動の関連性についての素朴理論を 確かに持っており，それが当初の予測とは異なる形で 影響を及ぼしたとも考えられる。すなわち，ポジティ ブな動機に基づくネガティブな行動は素朴理論に反す る行動情報であるがゆえに，他の行動に比べてより多 くの注意が向けられ，より精緻な情報処理がなされた ために再生数が高まったのかもしれない。

もし，ポジティブな動機に基づくネガティブな行動 の再生が作業記憶において精緻な処理を受けたために 多くなったのであれば，そのような精緻な処理を妨げ るような認知負荷を実験参加者にかけることは，ポジ ティブな動機に基づくネガティブな行動の再生にのみ 顕著に影響するはずである。そして，素朴理論に一致 するその他の行動情報の再生は，認知負荷の影響をあ まり受けないと考えられる。事実，期待や信念に反す る社会的情報の処理がそうでない情報よりも認知負荷 の影響をより大きく受けることが多くの研究で示され ている（Bargh \& Thein, 1985)。それに加えて, 先述 のように Ybarra \& Stephan (1996, Experiment 3) も, 行動情報を符号化する際に認知負荷（時間的圧力）を かけた実験群を統制群と比較し, 彼らのいう素朴理論
に合致する行動情報の再生が認知負荷の影響を受けに くいことを示した。以上の知自を参考にして, 続く研 究 2 では, 行動情報の符号化時に認知負荷をかける群 と認知負荷をかけない統制群を設定して行動情報の再 生パターンを比較する。

\section{研 究 2}

研究 1 でポジティブな動機に基づくネガティブな行 動の再生数が多かったのが素朴理論に反する情報であ るためにより多くの注意が向けられ，より入念な処理 がなされた結果であるのなら，その行動情報の再生数 は, 時間的圧力をかけられた実験参加者群（負荷あり 条件）の方が，時間的圧力をかけられない実験参加者 群（負荷なし条件）よりも顕著に少なくなると考えら れる。一方で, 素朴理論に一致するその他の種類の行 動情報の再生数は，ポジティブな動機に基づくネガテ イブな行動よりは認知負荷の有無による再生数の差異 が小さいと考えられる。すなわち, 行動の種類と認知 負荷との交互作用が予測され, 認知負荷の効果はポジ ティブな動機に基づくネガティブな行動の再生により 顕著に表れると予測される。

\section{方 法}

実験参加者と実験計画, 行動記述文 実験参加者は 31 名の大学生（すべて女性）であった。実験計画は 4 (行動の種類 $) \times 2$ (認知負荷の有無）の混合要因計画 で, 前者は参加者内要因, 後者は参加者間要因であっ た。負荷あり条件に 16 名, 負荷なし条件に 15 名がラ ンダムに振り分けられた。使用した行動記述文とその 提示を制御する実験装置は研究 1 と同じであった。

手続き 実験手続きは研究 1 とほぼ同じだが，以下 の 3 点で異なっていた。(a)すべての実験は 1 人ずつ 行われた。(b) 各行動記述文の提示時間は, 負荷なし 条件で 10 秒間，負荷あり条件で 3 秒間であった。提 示間隔は両条件ともに 1 秒であり, 研究 1 と同じくこ の間に注視点が提示された。(c) 行動記述文の提示時 間が短い負荷あり条件では研究 1 のような評定用紙を 用いた好ましさの評定が困難なので, 両条件ともに行 動の好ましさは口頭で評価してもらった（好ましいと 思う場合は “マル”，好ましくないと思う場合は“バ ツ”。行動記述文が提示されている間に評価できなか つた場合でも，慌てずに次の行動の評価をするよう教 示した。

\section{結果と考察}

行動の評価 行動の種類ごとに“マル” と回答され た行動の数の平均を求め, その值を従属変数として 4 (行動の種類) $\times 2$ (認知負荷の有無）の ANOVA を行 った（時間内に評価できなかった行動が一つ以上ある 負荷あり条件の 5 名の実験参加者はこの分析からは除 
外した)。その結果，行動の種類の主効果が有意であ った $(F(3,72)=127.20, p<.01)$ 。また, 交互作用も 有意であった $(F(3,72)=4.28, p<.01)$ 。Ryan 法に よる多重比較の結果, 負荷なし条件ではすべての行動 の種類の間に有意差がみられ $(p s<.01)$, ポジティブ な動機に基づくポジティブな行動（ $M=4.73, S D=$ 0.70), ポジティブな動機に基づくネガティブな行動 $(M=3.40, S D=1.30)$, ネガティブな動機に基づくポ ジティブな行動 $(M=2.07, S D=1.10)$ ，ネガティブ な動機に基づくネガティブな行動 $(M=0.20, S D=$ 0.41）の順に好ましいと判断された行動の数が多かっ た。これは研究 1 の評価のパターンと同じであった。

負荷あり条件では, ポジティブな動機に基づくポジ ティブな行動のほとんどが好ましいと判断されており $(M=4.91, S D=0.30)$, どの種類の行動と比較しても 好ましいと判断された数は有意に多かった $(p \mathrm{~s}<$ .01)。また，ネガティブな動機に基づくネガティブな 行動は好ましいと判断されることはほとんどなく $(M=0.09, S D=0.30)$, どの種類の行動と比較しても 好ましいと判断された数が少なかった $(p s<.01)$ 。負 荷なし条件と異なるのが，ネガティブな動機に基づく ポジティブな行動 $(M=3.09, S D=1.14)$ とポジティ ブな動機に基づくネガティブな行動 $(M=2.73$, $S D=1.10)$ の間で好ましいと判断された行動記述文 の数の平均に有意な差がみられない点である（ $t<$ 1)。しかしながら, 認知負荷の有無は行動の評価に多 少の影響を与えていたが，どちらの条件でもポジティ ブな動機に基づくポジティブな行動とネガティブな動 機に基づくポジティブな行動の評価の間に，また，ポ ジティブな動機に基づくネガティブな行動とネガティ ブな動機に基づくネガティブな行動の評価の間に有意 な差がみられたことから，負荷あり条件でも負荷なし 条件でも, 研究 1 の結果と同様に実験参加者は実験者 の意図した通りの動機を推論していたといえよう。

行動の記憶 研究 1 と同様に, 2 人のコーダーによ つて実験参加者の回答が評価された。一致率は $95.4 \%$ であった。コーダー間で一致しなかった回答は両者の 話し合いによって正再生とみなすかどうかが判断され た。行動の種類ごとに平均正再生数を算出し, 4 (行 動の種類) $\times 2$ (認知負荷の有無）の ANOVA を行っ た (Figure 2)。その結果, 行動の種類の主効果 $(F(3,87)=3.78, p<.02)$ と認知負荷の主効果 $(F(1$, $29)=8.68, p<.01)$ が有意であった。より重要なこと に，交互作用が有意であった $(F(3,87)=3.63, p<$ .02)。負荷なし条件に抢ける行動の種類の単純主効果 が有意であり $(F(3,87)=7.04, p<.01)$, Ryan 法によ る多重比較の結果, ポジティブな動機に基づくネガテ ィブな行動はポジティブな動機に基づくポジティブな 行動よりも有意に再生数が多く $(t(87)=3.88, p<$ .02)，また，ネガティブな動機に基づくポジティブな
行動と比較しても有意に再生数が多かった $(t(87)=$ $3.68, p<.02)$ 。ポジティブな動機に基づくネガティブ な行動の再生数とネガティブな動機に基づくネガティ ブな行動の再生数との差は有意傾向であった（ $t$ $(87)=2.13, p<.08)$ 。ポジティブな動機に基づくポジ ティブな行動とネガティブな動機に基づくポジティブ な行動の再生数の間に有意な差はなかった $(t<1)$ 。 この負荷なし条件の再生パターンは研究 1 とほぼ同じ であった。負荷あり条件では, 最もネガティブに評価 されたネガティブな動機に基づくネガティブな行動が 他の行動に比べてやや再生数が多かったが, 行動の種 類の単純主効果は有意ではなかった $(F<1)$ 。

仮説の検証にとって重要なのは, 認知負荷が行動の 種類ごとに異なる影響を及ぼしているかどうかであ る。単純主効果の検定の結果, ポジティブな動機に基 づくネガティブな行動においてのみ認知負荷が影響し て抢り，負荷なし条件よりも負荷あり条件の方が有意 に再生数が少なかった $(F(1,116)=18.73, p<.01)$ 。 その他の行動では認知負荷の効果は有意ではなかった $(F \mathrm{~S}<1)$ 。

以上の結果は，ポジティブな動機に基づくネガティ ブな行動の再生数には認知負荷がある条件とない条件 とで有意な差があり, その他の行動では差がないとい う予測と一致していた。このことは，ポジティブな動 機に基づくネガティブな行動は人々が持っている信念 に反しており，その他の行動は信念に合致していると いうことを示唆している。

ところで, もし本研究で提案するような動機と行動 の関連性についての素朴理論を人々が持っているとす るならば，その素朴理論に一致する情報の処理は認知 負荷による妨害を顕著には受けないと予測していた。 もしそうであるのなら, 負荷あり条件では, 素朴理論 に一致する行動情報の再生数は素朴理論に反する行動 情報の再生数よりも多くなると考えるのが自然であろ う。しかしながら, 結果としては負荷あり条件の行動

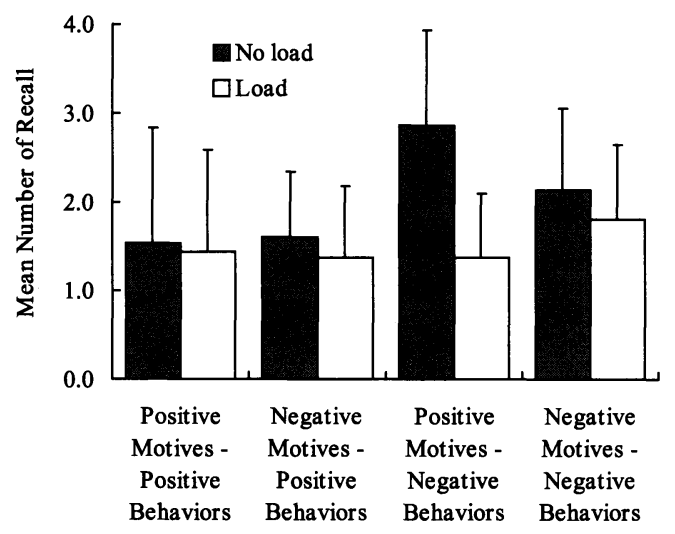

Figure 2. Mean free recall by behavior type and cognitive load. 
情報の再生数はどの行動の種類の間にも有意な差はみ られなかった。そのため，素朴理論に反する行動情報 の処理が認知負荷の影響を顕著に受けたという結果が 素朴理論の存在を示唆してはいるものの, 必ずしもそ れを積極的に支持するものとはいえないだろう。そこ で, 続く研究 3 では, 素朴理論が存在するのかどうか を，行動から動機を推測するという課題を用いてより 直接的に検証する。

\section{研 究 3}

研究 3 では, 実際に行動から動機を推論するとき に, 本研究で提案するような素朴理論に沿った推論を するかどうかをより直接的に検証する。調查協力者に 複数のポジティブな行動とネガティブな行動が記述さ れた質問紙を配布し，それらの行動から行為者の動機 を想像して自由記述してもらう。もし, 人が先述のよ うな素朴理論を持っているのであれば，ポジティブな 行動から動機を推論するときには, 行動と同じ好まし さの動機（i.e., ポジティブな動機）を推論しやすいだ けでなく，行動の好ましさに反する好ましさの動機 (i.e., ネガティブな動機) にも言及すると考えられる。 一方で，ネガティブな行動から動機を推論する場合に は,もっぱら行動と同じ好ましさの動機（i.e., ネガテ イブな動機）に言及し，行動の好ましさに反する好ま しさの動機（i.e., ポジティブな動機）を推論する程度 は低いと予測される。

\section{方 法}

調査協力者 145 名の大学生（女性 101 名, 男性 44 名）であった。欠損值のあった 12 名の回答と質問紙 に記載されていた教示の意味を理解していなかった 1 名の回答は分析から除外した。

行動記述文 提示した行動記述文はポジティブな行 動を表した七つの行動記述文 (e.g., 㧍年寄りに席を譲 つた）とネガティブな行動を表した七つの行動記述文 (e.g., 犬に石を投げつけた) であった。これらの行動 記述文は, 研究 1 で述べた予備調査の “行動のみ”の 好ましさの評定平均值に基づいて選ばれており, 研究 1 と研究 2 で使用された行動記述文とは異なり, 動機 の推論を容易にするような文脈情報は含まれていなか つた。ポジティブな行動を表した七つの行動記述文の 評定平均値 $(M=5.81-6.19, S D=0.77-0.98)$ はそ れぞれ中点よりも有意に高く $(p \mathrm{~s}<.01)$ ，ネガティブ な行動を表した七つの行動記述文の評定平均値 $(M=1.19-2.63, S D=0.45-1.16)$ はそれぞれ中点よ りも有意に低かった $(p s<.01)^{8}$ 。

8 七つの行動の評価の平均を比較したとき, その極端さ（中 点からの乘離) には七つのポジティブな行動 $(M=1.95)$ と七 つのネガティブな行動 $(M=2.08)$ との間に有意な差はなかっ た $(t<1.38)$ 。
手続き 調査は大学の授業時間の一部を利用して実 施した。質問紙は，行動記述文を読んでその好ましさ を 7 件法（1：非常に好ましくない一7：非常に好まし い）で回答してもらう評価課題と，それぞれの行動記 述文から行為者の動機を推論する推論課題に分かれて いた。推論課題には以下のような教示文が付されてい た。“人は，様々な意図・目的（動機）を持って行動 しています。以下には, いろいろな人物が行ったいく つかの行動が記述されています。それぞれの行動につ いて，‘なぜそのような行動を行ったか，その行動を 行った意図・目的（動機）は何か’を，あなたなりに 自由に想像して記述してください。回答には正解や不 正解はありません。思いついたものを自由に押書きく ださい。”なお，それぞれの行動から二つの動機を自 由に推論してもらい回答欄に記述してもらった゚。評 価課題も推論課題も行動記述文はランダムに配列され ていた。さらに, 評価課題と推論課題の両者ともに, 前半の 7 文と後半の 7 文を入れ替えたもう 1 種類の質 問紙を用意し, 調査協力者に対してランダムに配布し た。

\section{結果と考察}

コーディング 自由記述は，2 人のコーダーが F. Ex コーディング・スキーマ（Malle, 2004）に基づい て，(a)ある行動が無意図的行動であるとみなされた 場合になされる要因説明 (cause explanations), (b) 行為者の動機や意図に言及する理由説明（reason explanations), (c) 行為の理由に先立ち, その理由を 引き起こすような要因に言及する理由の因果履歴説明 (causal history of reason explanations)，(d)ある意図 的行動を完遂するのがいかにして可能であったかを説 明する可能要因説明 (enabling factor explanations) という四つのカテゴリーに大別した ${ }^{10}$ 。その後に，動 機や意図に言及する理由説明に含まれた自由記述をそ の好ましさに応じてポジティブ，ネガティブ，ニュー トラルに分類した。分析に用いたのはポジティブな理

9 もし人が本研究で提案したような動機と行動の関連性につ いての素朴理論を持っているのであれば, 動機の推論の特徵は, 行動の好ましさに反する好ましさの動機を推論する割合の違い に表れるはずである。ところが，行動の好ましさに反する好ま しさの動機を推論することは, 一致する好ましさの動機を推論 するのに比べて認知的な労力が必要であるかもしれない。その ため, 行動から動機を一つだけしか推論させないのであれば, 一致する好ましさの動機が推論されやすくなり，もし素朴理論 を持っていたとしてもそれがこの指標では検出されにくくなる。 本研究では測度の敏感さを上げるために二つの動機を推論して もらった。

10 F. Ex では単文が分類対象となるが, 研究 3 の調査協力者の 自由記述に重文は含まれていなかった。したがって, 各調査協 力者が 14 の行動に二つずつ行動説明をしたため, 合計で 3696 個の自由記述が分類の対象となった。これらの分類の詳細につ いては, Malle（2004, Chapter 4, Appendix）を参照。 
Table 1

Mean number ( $S D$ in parentheses) of inferred motives

\begin{tabular}{lcc}
\hline & \multicolumn{2}{c}{ Favorability of inferred motives } \\
\cline { 2 - 3 } $\begin{array}{l}\text { Favorability } \\
\text { of behaviors }\end{array}$ & $\begin{array}{c}\text { Consistent } \\
\text { with behaviors }\end{array}$ & $\begin{array}{c}\text { Inconsistent } \\
\text { with behaviors }\end{array}$ \\
\hline Positive & $4.79(2.26)$ & $1.71(1.73)$ \\
Negative & $5.54(2.15)$ & $0.84(1.01)$ \\
\hline
\end{tabular}

由説明とネガティブな理由説明であり, 今回の研究目 的とは関係のないその他のカテゴリーに含まれた自由 記述は分析に用いなかった。 2 人のコーダーによる分 類の一致率は $85.6 \%(x=.81)$ であった。分類が一致 しなかった自由記述は 2 人のコーダーの話し合いによ ってどのカテゴリーに含まれるかが決定された。

行動の評価 七つのポジティブな行動に対する評価 はすべてが中点よりも有意に高く $(p s<.01)$, 七つの ネガティブな行動に対する評価はすべてが中点よりも 有意に低かった $(p \mathrm{~s}<.01)$ 。以上の結果から, 調查者 の意図通りポジティブな行動はポジティブに，ネガテ イブな行動はネガティブに評価されていたことが確認 された。

動機の推論 ネガティブな行動とポジティブな行動 のそれぞれについて，行動の好ましさと同じ好ましさ の動機を推論しているとみなされた自由記述の数の平 均と標準偏差，行動の好ましさに反する好ましさの動 機を推論しているとみなされた自由記述の個数の平均 と標準偏差を Table 1 に示す。自由記述の個数を従属 変数として, 2 (行動：ポジティブ, ネガティブ) $\times 2$ (動機の好ましさ：行動の好ましさと一致, 行動の好 ましさと不一致）の ANOVA を行った ${ }^{11}$ 。その結果, 動機の主効果が有意であり $(F(1,131)=470.76, p<$ .01), 行動と同じ好ましさの動機が, 行動に反する好 ましさの動機よりもより多く推論されていた。より重 要なことに，交互作用が有意であった $(F(1,131)=$ 21.74, $p<.01)$ 。Table 1 に示されているように，ネ ガティブな行動からその好ましさに反する好ましさの 動機（i.e., ポジティブな動機）を推論する傾向は，ポ ジティブな行動からその好ましさに反する好ましさの 動機（i.e., ネガティブな動機）を推論する傾向よりも 有意に低かった $(F(1,262)=354.03, p<.01)$ 。

この結果は予測を支持している。すなわち，人はネ ガティブな行動からはもつぱらネガティブな動機を推 論し, ポジティブな行動からはポジティブな動機とと もに，ネガティブな動機をも少なからず推論する傾向 にあった。ただし，ポジティブな行動からポジティブ な動機が推論される傾向とネガティブな動機が推論さ れる傾向の間にも有意な差があった $(F(1,262)=$

11 理由説明をした総数を分母とした “割合”を用いて分析して も同様の結果が得られた。
$151.81, p<.01)$ 。この研究で用いた行動記述文のよう に動機の推論を容易にするような文脈情報が含まれて ない行動情報から動機を推論するときには（すなわ ち，行動だけを見て動機を推論するときには)，そも そも行動の好ましさに反する好ましさの動機を推論す ることにより多くの認知的労力が必要であるのかもし れない。そして，人は“認知的倹約家”であるため (Fiske \& Taylor, 1991), ネガティブな行動からはネ ガティブな動機を推論し，ポジティブな行動からはポ ジティブな動機を推論しやすいと考えられる。しかし ながら，それにもかかわらず，ポジティブな行動から はネガティブな動機が比較的推論されやすい傾向が示 されたのは，そのような推論を導く何らかの要因があ ったことを意味している。それは，ポジティブな行動 とネガティブな動機を関連づけている素朴理論の働き ということになるだろう。

\section{総合考察}

本研究では, 人が動機と行動の関連性についての素 朴理論を持っているということが提案された。その素 朴理論は，ネガティブな行動はネガティブな動機と, そしてポジティブな行動はポジティブな動機とネガテ イブな動機の両者と関連づけられているというもので あった。研究 1 と研究 2 では, 行動情報の再生記憶を 指標として, 人が素朴理論を持っているかどうかが検 証された。行動情報の符号化時に認知負荷がない条件 では, 素朴理論に反している行動情報（i.e., ポジティ ブな動機に基づくネガティブな行動）は他の行動情報 よりも再生数が多かった。ところが，符号化時に認知 負荷をかけた場合には，素朴理論に反する行動情報の 再生数は大きく減少し，しかも減少の仕方が他の行動 情報に比べて顕著であった。以上の結果は, ポジティ ブな動機に基づくネガティブな行動が人々の持ってい る信念に反していること，それ以外の行動は人々の信 念に合致しているということを示唆している。研究 3 では，もし人が上記の素朴理論を持っているのであれ ば，行動からの動機の推論はその素朴理論に方向づけ られると予測された。調査協力者に行動から動機を推 論し自由記述してもらったところ，ネガティブな行動 からはもっぱらネガティブな動機が推論されていた が，ポジティブな行動からはポジティブな動機が推論 されやすいだけでなく，ネガティブな動機も少なから ず推論される傾向にあった。以上の三つの研究の結果 は, 人が本研究で提案したような動機と行動の関連性 についての素朴理論を持っていることを強く示唆する ものである。

Malle（1999）は，人が他者の意図的行動を説明す るときに行為者の意図や動機に言及することを明らか にした。本研究で得られた知見によって示唆されるの は，その言及の仕方にも一定の偏りが生じるかもしれ 
ないという点である。すなわち，行動の種類によって 言及されやすい動機が異なっており，特に興味深いの は，ポジティブな行動を説明するときにはネガティブ な動機にも言及する可能性があるという点である。ネ ガティブな社会的刺激に敏感に反応するというネガテ イビティ・バイアスが人の心理現象の様々な領域で確 認されているが (Baumeister, Bratslavsky, Finkenauer, \& Vohs, 2001), 本研究が示唆しているのは, 動機の 推論においては, ポジティブな行動からもネガティブ な行動からもネガティブな動機を推論する傾性を持っ ているという点で, 人はネガティブな動機により敏感 であるという可能性である。ネガティブな動機を推論 しやすいということは, 悪意を隠し持つ他者がもたら すかもしれない不利益を回避する可能性を結果として 高めることにつながるであろう。そのため，このよう な推論傾向を持っていることは適応的であるといえる かもしれない。

ここで, 本研究で実証した動機と行動の関連性につ いての素朴理論と, Ybarra（2002）の行動について の因果理解に関する理論との関係を考察しておこう。 両者は，ポジティブな，あるいはネガティブな行動に 対して人々が行っている因果分析について記述してい るという点では共通している。しかしながら, 両者の 間には, その前提に根本的な相違点があることを指摘 しておきたい。人が他者の行動を因果分析するとき， 行動の原因を行為者か状況のどちらかに帰属するとい ういわゆる“人一状況の二分法” (person-situation dichotomy）は帰属理論の伝統的な考え方であった。 先に解説したように, Ybarra (2002) の理論もこの 二分法を前提としている。しかしながら, Malle （2004）をはじめとする近年の㷌属理論研究者たちは, この単純な二分法に対して強烈な批判を加えている。 行動の原因を人か状況に峻別することは現実には困難 であり，過去の帰属理論研究の手法では，それを実験 者が恣意的に区別してきたか，あるいは区別するよう に実験参加者に強制してきたに過ぎないというのが彼 らの主張である12。そして, 実際に他者の行動を理解 するときには，人は“なぜその行動を行ったか”を知 ろうとし, 行為者の動機や意図といった心的状態を推 論するのが自然であると彼らは主張する。本研究で提 案した動機と行動の関連性についての素朴理論は, こ のような主張と軌を一にしているものといえる。先述 した Ybarra (2002) と本研究の根本的な相違とは, 他者の行動を理解するために人が持っている認識の枠 組みとして人一状況の二分法を前提とするか，あるい は心的状態の理解を中心とした認識の枠組みを前提と するかの違いである。本研究は, ポジティブな, ある

12 ただし, Malle (2004) は, 成功や失敗といった“行為の結 果” は意図的行動ではないため，人一状況の二分法を採用する ことは不適切ではないと論じている。
いはネガティブな行動を理解するにあたって，人一状 況の二分法を採用するのが本当に適切であるかを直接 的に検証したものではなく，動機の推論においても特 定のパターンがみられることを示した研究である。そ のため, 本研究で提案した素朴理論が, Ybarra (2002) の提唱する素朴理論よりも妥当性が高いとは 必ずしも言い切れないが, 近年の帰属理論の発展を踏 まえれば，動機という概念を用いた本研究は，人の行 動理解をより適切な形でとらえているといえるのでは ないだろうか。今後は, 両者を直接的に比較し, どち らの素朴理論がより適切に人の行動理解を表現してい るかを検証できるような研究が求められる。

\section{引用文献}

Bargh, J. A., \& Thein, R. D. (1985). Individual construct accessibility, person memory, and the recalljudgment link: The case of information overload. Journal of Personality and Social Psychology, 49, 1129-1146.

Baumeister, R. F., Bratslavsky, E., Finkenauer, C., \& Vohs, K. D. (2001). Bad is stronger than good. Review of General Psychology, 5, 323-370.

Fiske, S. T., \& Taylor, S. E. (1991). Social cognition. 2nd ed. New York: McGraw-Hill.

Kammrath, L. K., Mendoza-Denton, R., \& Mischel, W. (2005). Incorporating if ...then ...personality signatures in person perception: Beyond the personsituation dichotomy. Journal of Personality and Social Psychology, 88, 605-618.

Macrae, C. N., Bodenhausen, G. V., Schloerscheidt, A. M., \& Milne, A. B. (1999). Tales of unexpected: Executive function and person perception. Journal of Personality and Social Psychology, 76, 200213.

Malle, B. F. (1999). How people explain behavior: A new theoretical framework. Personality and Social Psychology Review, 3, 23-48.

Malle, B. F. (2004). How the mind explains behavior: Folk explanations, meaning, and social interaction. Cambridge, MA: MIT Press.

McClure, J. (2002). Goal-based explanations of actions and outcomes. In W. Stroebe \& M. Hewtone (Eds.), European Review of Social Psychology. Vol. 12. New York: Wiley. pp. 201-235.

Miller, J. G. (1984). Culture and the development of everyday social explanation. Journal of Personality and Social Psychology, 46, 961-978.

Reeder, G. D., Vonk, R., Ronk, M. J., Ham, J., \& Lawrence, M. (2004). Dispositional attribution: Multiple inferences about motive-related traits. Journal of Personality and Social Psychology, 86, 530-544.

Ybarra, O. (2002). Naive causal understanding of valenced behaviors and its implications for social information processing. Psychological Bulletin, 
128, 421-441.

Ybarra, O., \& Stephan, W. G. (1996). Misanthropic person memory. Journal of Personality and
Social Psychology, 70, 691-700.

- 2005.6.10 受稿, 2006.5.7 受理-— 